\title{
The Elimination of Urease Activity in Streptococcus faecium as Evidence for Plasmid-coded Urease
}

\author{
By A. R. COOK \\ The Rowett Research Institute, Bucksburn, Aberdeen AB2 $9 S B$
}

(Received 24 March 1975; revised 29 May 1975)

\section{SUMMARY}

A strain of Streptococcus faecium from the sheep rumen showed spontaneous loss of urease activity when subcultured at the normal rumen temperature of $38^{\circ} \mathrm{C}$, although in mixed cultures in vivo or in vitro loss of urease was not apparent. The rate of loss of urease in pure cultures was increased at incubation temperatures above $38{ }^{\circ} \mathrm{C}$, but loss was never complete. However, at temperatures below $38^{\circ} \mathrm{C}$ loss was greater, and at 22 or $18{ }^{\circ} \mathrm{C}$ the urease was completely eliminated. Incubation with sodium dodecyl sulphate $(0.002 \%)$ or ethidium bromide $\left(2.5 \times 10^{-5} \mathrm{M}\right)$ caused complete loss of urease activity. The urease activity was also eliminated when the streptococcus was grown aerobically, and this loss of activity was irreversible.

It is suggested that the urease activity is controlled by a plasmid gene and that aeration, low growth temperature and chemical agents 'cure' the streptococcus of the plasmid. Attempts to demonstrate the presence of covalently closed circular extrachromosomal DNA by caesium chloride-ethidium bromide equilibrium density-gradient centrifugation were unsuccessful.

\section{INTRODUCTION}

During the isolation of a ureolytic strain of Streptococcus faecium from the rumen of a sheep it was observed that the urease activity was an unstable property. Also, this nutritionally-fastidious streptococcus was unable to utilize ammonia as a source of nitrogen, and growth of either a urease-free strain or a ureolytic strain was not affected by addition of urea to a complex medium (Cook, 1976). Thus the presence of the urease was not essential for the survival of the bacterium. The results suggested that the ureolytic activity of the streptococcus might be coded on a plasmid (Cook, 1976).

The spontaneous loss of a plasmid genetic trait may be increased by growth under certain physical conditions and by growth in the presence of 'curing agents' (Novick, 1969; Clowes, 1972). The collective results of such experiments have been used to provide evidence that urease in $S$. faecium is coded on a plasmid. Plasmids exist as autonomously replicating DNA molecules physically separate from the host chromosome and in a covalently closed circular (CCC) form which has been isolated from several bacteria with extrachromosomal properties (Bazaral \& Helinski, 1968; Christiansen et al. 1973). An attempt was made to isolate a plasmid DNA species from the $S$. faecium.

\section{METHODS}

Bacteria. The ureolytic strain of Streptococcus faecium was isolated from the rumen of a sheep (Cook, 1976). Proteus mirabilis NCiB60 was obtained from the National Collection of Industrial Bacteria, Torry Research Station, Aberdeen. The ureolytic strain of Peptostreptococcus provostii was isolated from the rumen of a calf on a molasses-urea diet (Elias, 1971). Cultures were incubated at $38^{\circ} \mathrm{C}$ unless otherwise stated. 
Chemicals. Brain-heart infusion and urea agar base were from Oxoid. Bactocasitone, Bactopeptone, Bactotryptone, Bacto yeast extract and agar were from Difco. BRIJ-58 was from Serva and supplied by Micro-Bio Laboratories Ltd, London. All other chemicals were from BDH. Glass-distilled water was used throughout. Carbon dioxide (British Oxygen Company, London) was passed over heated copper to give an oxygen-free supply.

Media. The SBU medium for S. faecium contained, per $100 \mathrm{ml}$ glass-distilled water: $0 . \mathrm{I} \mathrm{ml}$ resazurin ( $0 . \mathrm{I} \%), 0.5 \mathrm{~g}$ Bactocasitone, $0.5 \mathrm{~g}$ yeast extract, $0.2 \mathrm{~g}$ mannitol, $0.05 \mathrm{~g}$ anhydrous sodium acetate, $0.075 \mathrm{~g}$ sodium thioglycollate, $0.5 \mathrm{~g} \mathrm{KH}_{2} \mathrm{PO}_{4}, 0.5 \mathrm{~g} \mathrm{Na}_{2} \mathrm{HPO}_{4}$, $0.2 \mathrm{~g}$ urea. The medium, without urea, was adjusted to $\mathrm{pH} \mathrm{7.4}$, sterilized by autoclaving at $\mathrm{I} 2 \mathrm{I}{ }^{\circ} \mathrm{C}$ for $15 \mathrm{~min}$, and a Seitz-filtered urea solution ( $\mathrm{I} \mathrm{ml} \mathrm{of} 20 \%$, w/v) was added under anaerobic conditions (oxygen-free $\mathrm{CO}_{2}$ ). When necessary the medium was dispensed under $\mathrm{CO}_{2}$. The final $\mathrm{pH}$ was 6.8 . Initially the medium was inoculated with a $2 \%(\mathrm{v} / \mathrm{v})$ inoculum and incubated for $24 \mathrm{~h}$ under $\mathrm{CO}_{2}$. In later experiments the inoculum size was reduced to $0.3 \%$. Other media used were SBY, which was similar to SBU except that urea was omitted, and SU and SY which were similar to SBU and SBY respectively except that Bactocasitone was omitted. The final pH of media SY and SBY was 6.6. Cultures were checked for purity by streaking a loopful on a brain-heart infusion agar plate which was incubated aerobically for $24 \mathrm{~h}$.

The medium (PMU) used for $P$. mirabilis contained, per $100 \mathrm{ml}: 0.75 \mathrm{~g} \mathrm{Na}_{2} \mathrm{HPO}_{4}, 0.75 \mathrm{~g}$ $\mathrm{KH}_{2} \mathrm{PO}_{4}, 0.01 \mathrm{~g} \mathrm{MgSO}_{4} .7 \mathrm{H}_{2} \mathrm{O}, 0.5 \mathrm{~g}$ Bactopeptone, $\mathrm{I} \mathrm{ml}$ nicotinic acid (0.I \%). The medium was adjusted to $\mathrm{pH} 6.5$ and, after sterilization by autoclaving at $121{ }^{\circ} \mathrm{C}$ for $15 \mathrm{~min}, \mathrm{I} \mathrm{ml}$ of a Seitz-filtered solution containing urea and glucose was added to give final concentrations of $0.015 \%$ glucose and $0.06 \%$ urea. The medium was dispensed as $5 \mathrm{ml}$ lots into $50 \mathrm{ml}$ conical flasks, inoculated with a $0.6 \%$ inoculum and incubated for $24 \mathrm{~h}$ on an orbital shaker (G24 environmental incubator shaker, New Brunswick Scientific Co., New Brunswick, New Jersey, U.S.A.). Culture purity was checked by microscopic examination.

Peptostreptococcus provostii was grown in medium AE which contained, per $100 \mathrm{ml}$ : $0 . \mathrm{I} \mathrm{ml} \mathrm{resazurin} \mathrm{(0.1 \% ),7.5} \mathrm{ml} \mathrm{mineral} \mathrm{solution} \mathrm{A}\left(6 \mathrm{~g} \mathrm{~K}_{2} \mathrm{HPO}_{4} / 1\right), 7.5 \mathrm{ml}$ mineral solution $B$ $\left(6 \mathrm{~g} \mathrm{KH}_{2} \mathrm{PO}_{4}, 12 \mathrm{~g} \mathrm{NaCl}, \mathrm{I} \cdot 2 \mathrm{~g} \mathrm{MgSO}_{4} .7 \mathrm{H}_{2} \mathrm{O}, \mathrm{I} \cdot 2 \mathrm{~g} \mathrm{CaCl}_{2} / 1\right)$, $0.5 \mathrm{~g}$ yeast extract, $0.5 \mathrm{~g}$ Bactotryptone, I ml FeSO ${ }_{4} \cdot 7 \mathrm{H}_{2} \mathrm{O}(0.34 \%)$, I ml CuSO${ }_{4} .5 \mathrm{H}_{2} \mathrm{O}(0.15 \%)$. After sterilization by autoclaving at $12 \mathrm{I}{ }^{\circ} \mathrm{C}$ for $\mathrm{I} 5 \mathrm{~min}$, $10 \mathrm{ml}$ Seitz-filtered solution $\mathrm{R}(0.2 \mathrm{~g}$ sucrose, $0.4 \mathrm{~g}$ $\mathrm{NaHCO}_{3}, 0.05 \mathrm{~g}$ cysteine- $\mathrm{HCl}$ ) was added and the complete medium dispensed in $10 \mathrm{ml}$ portions under oxygen-free $\mathrm{CO}_{2}$. The medium was inoculated with a $0.3 \%$ inoculum and incubated for $24 \mathrm{~h}$ under anaerobic conditions. Culture purity was checked by microscopic examination.

Colony-forming unit (c.f.u.) determinations. For Streptococcus faecium and Proteus mirabilis, these were carried out by making serial tenfold dilutions in brain-heart infusion broth and mixing $0.5 \mathrm{ml}$ samples from the dilution in $10 \mathrm{ml}$ brain-heart infusion agar in a $90 \mathrm{~mm}$ diameter Petri dish (Sterilin Ltd., Teddington, Middlesex) followed by a $48 \mathrm{~h}$ aerobic incubation. With Peptostreptococcus provostii, serial tenfold dilutions were carried out using a dilution fluid similar to medium $\mathrm{AE}$ except that $\mathrm{FeSO}_{4} \cdot 7 \mathrm{H}_{2} \mathrm{O}, \mathrm{CuSO}_{4} \cdot \mathrm{H}_{2} \mathrm{O}$ anc sucrose were omitted. A $0.5 \mathrm{ml}$ sample of an appropriate dilution was added to $4.5 \mathrm{ml}$ of medium AE with $2 \%(w / v)$ agar in a test tube and a roll tube prepared which was incubated for $72 \mathrm{~h}$. For any dilution the sampling was done in triplicate and only those plates or roll tubes with c.f.u. counts between 30 and 300 were considered significant.

Growth. Bacterial density was determined at $650 \mathrm{~nm}$ as previously described (Cook, 1976).

Urease activity. The units of urease activity (i.u./ml) were previously defined (Cook, 1976). A sample $(\mathrm{I} \mathrm{ml})$ of culture was resuspended in either 2 or $4 \mathrm{ml}$ of assay buffer $(0.02 \mathrm{M}$ - 
sodium phosphate buffer $\mathrm{pH} 7.0$, containing $0.00 \mathrm{I}$ M-EDTA) and 0.2 or $0.1 \mathrm{ml}$ of cell suspension was assayed as previously described (Cook, 1976). A loopful of an isolate of Peptostreptococcus provostii on AE slopes was resuspended in $0.2 \mathrm{ml}$ of assay buffer and assayed by the rapid method (Cook, 1976).

. Inoculum size and culture urease activity. In one series, $\mathrm{SY}$ medium (Io $\mathrm{ml}$ ) was inoculated with a $0.3 \%$ inoculum from a $24 \mathrm{~h}$ culture grown in medium SU, and after incubation for $24 \mathrm{~h}$ the culture was the source of inoculum $(0.3 \%$ ) for SY (Io ml) and SU (I0 ml) media, which were then incubated for $24 \mathrm{~h}$. The subculturing of the previous culture grown in SY medium into SY and SU media was repeated for up to 2I consecutive daily transfers. In another series, SBY and SBU media were used. The control in both series was an inoculum size of $2 \%(v / v)$. After $24 \mathrm{~h}$ incubation the bacterial density was measured at $\mathrm{E}_{650}$ and the urease activity determined.

Temperature treatment. SU and SBU media were inoculated from a $24 \mathrm{~h}$ culture with a $0.3 \%$ inoculum, and incubated for $24 \mathrm{~h}$ at temperatures between 18 and $48{ }^{\circ} \mathrm{C}$, after which the urease activity and bacterial density were measured. At each temperature there were four successive subcultures, and when a culture was not ureolytic or when the urease activity was very low, then this culture was subcultured into the same medium and incubated at $38^{\circ} \mathrm{C}$. If the subculture grown at $38^{\circ} \mathrm{C}$ was not ureolytic then up to $2 \mathrm{I}$ consecutive transfers were carried out, each incubated at $38^{\circ} \mathrm{C}$ for $24 \mathrm{~h}$. The control with either medium was incubated at $38^{\circ} \mathrm{C}$.

Sodium dodecyl sulphate (SDS) treatment. Medium SBU (Io $\mathrm{ml}$ ), with concentrations of SDS from 0.0005 to $0.005 \%$, was inoculated with a diluted stationary-phase culture grown in SBU medium, to give a final viable count of $10^{4}$ c.f.u./ml. After $24 \mathrm{~h}$ incubation the bacterial density, viable count and urease activity of each culture in which growth had occurred were determined, and for each of these cultures four consecutive daily subcultures $(0.3 \%)$ were made into SBU medium alone and SBU medium plus SDS at the same concentration. When a subculture in SBU medium alone was not ureolytic, 21 daily transfers on SBU medium were made to see if ureolytic activity was regained.

Ethidium bromide $(E B)$ treatment of $S$. faecium. A small inoculum (to give $10^{4}$ c.f.u./ml) from a diluted, overnight, stationary-phase culture grown in SBU medium was incubated in SBU medium ( $10 \mathrm{ml}$ ) containing EB at concentrations from $9 \times 10^{-8}$ to $4 \times 10^{-5} \mathrm{M}$. After overnight incubation the bacterial density, the viable count of those cultures with very low bacterial density and the urease activity were determined, and subcultures ( $0.3 \%$ inoculum) made into SBU medium with or without the same concentration of EB. Subculturing from the EB-containing medium into media with and without EB was carried out on four consecutive days. If a culture without EB showed no urease activity the ability to regain activity was tested by 2I daily transfers, as with SDS treatment.

Ethidium bromide treatment of P. mirabilis. An inoculum from a diluted overnight culture in PMU medium (to give $4 \times 10^{4}$ c.f.u. $/ \mathrm{ml}$ ) was added to flasks of PMU medium containing EB at concentrations from $5 \times 10^{-5}$ to $5 \times 10^{-4} \mathrm{M}$. The culture containing the highest concentration of EB in which visible growth had occurred in $24 \mathrm{~h}$ (culture A) was subcultured ( $0.3 \%$ inoculum) into medium containing EB at the same concentration. Similarly, the cultures from the next higher and the next lower concentrations of EB were subcultured into media containing the same concentration of EB. After $24 \mathrm{~h}$ the three cultures were subcultured once more. Bacterial density and urease activity was determined in all cultures. Culture $\mathrm{A}$ and the first subculture from this were diluted in brain-heart infusion broth and $0.5 \mathrm{ml}$ samples then dispensed in $10 \mathrm{ml}$ brain-heart infusion agar containing $0.2 \%$ urea, in a Petri dish, and incubated $48 \mathrm{~h}$. One hundred isolated colonies were inoculated on to urea- 
agar slopes and incubated $72 \mathrm{~h}$. As a control the same procedure was used on a culture which had been grown without EB.

Ethidium bromide treatment of Peptostreptococcus provostii. Tubes of AE medium containing EB at concentrations from $2 \times 10^{-6}$ to $4.5 \times 10^{-6} \mathrm{M}$ were inoculated (to give $\mathrm{I} \times 10^{4} \mathrm{c}$.f.u. $/ \mathrm{ml}$ ) from a diluted culture grown in AE medium. After incubation for $24 \mathrm{~h}$, the bacterial density and urease activity were determined to find the culture which had the highest concentration of EB in which growth occurred (culture B); a subculturing procedure, similar to that for $P$. mirabilis, was then followed for a total of four transfers, for this culture and those containing the next higher and lower concentrations of EB. Culture B was diluted and incubated in roll tubes for $72 \mathrm{~h}$, after which one hundred colonies were isolated on to AE slopes, incubated for $48 \mathrm{~h}$, and assayed for urease activity using the rapid method.

Aerobic growth of $S$. faecium. SBU medium $(105 \mathrm{ml})$ was modified by omitting sodium thioglycollate and adding one drop of propane-I,2-diol as antifoaming agent. The medium was aerated overnight with a $1600 \mathrm{ml} / \mathrm{min}$ air flow humidified by passage through water. The air supply passing through the water and medium was fragmented by use of gas distribution tubes with domed sintered glass bulbs of porosity o (Sinta Glass, Gallenkamp, London). For $30 \mathrm{~min}$ before inoculation and during growth, the aeration rate was increased to $3000 \mathrm{ml} / \mathrm{min}$ and a $5 \mathrm{ml}$ sample was removed as a blank for the measurement of bacterial density. The medium was then inoculated with a $0.3 \%$ inoculum from an overnight culture grown in SBU. Samples $(6 \mathrm{ml})$ were removed at $30 \mathrm{~min}$ intervals and after measuring the growth density the urease activity was determined by centrifuging a $5 \mathrm{ml}$ sample, resuspending the sediment in I $\mathrm{ml}$ of assay buffer and assaying $0.4 \mathrm{ml}$ for $30 \mathrm{~min}$ at $38^{\circ} \mathrm{C}$. At the sampling times, $2 \times 10 \mathrm{ml}$ lots of SBU medium, tubed under $\mathrm{CO}_{2}$, were inoculated $(0.3 \%)$ and incubated for either 24 or $48 \mathrm{~h}$. The bacterial density of these cultures was measured and the urease activity determined by resuspending $\mathrm{I} \mathrm{ml}$ culture, after centrifugation, in $\mathrm{I} \mathrm{ml}$ assay buffer and assaying $0.2 \mathrm{ml}$ for $5 \mathrm{~min}$ at $38^{\circ} \mathrm{C}$. In addition, the $24 \mathrm{~h}$ culture was subcultured into SBU medium and incubated anaerobically for $24 \mathrm{~h}$, after which the growth density and urease activity were determined. Those anaerobic cultures which were not ureolytic were subcultured for up to 2 I consecutive days.

Lysis and caesium chloride-ethidium bromide differential centrifugation. The method used was that of Courvalin, Carlier \& Chabbert (1972). A $0.3 \%$ inoculum of $S$. faecium was incubated in $100 \mathrm{ml} \mathrm{SBU}$ medium for $20 \mathrm{~h}$. The cells were harvested by centrifugation at $0{ }^{\circ} \mathrm{C}$ and, after two cold washings with $0.85 \% \mathrm{NaCl}$ containing $0.005 \mathrm{M}$-EDTA at $\mathrm{pH} 7 \cdot 0$, the sediment was resuspended in $10 \mathrm{ml}$ solution $\mathrm{NE}(2.5 \mathrm{M}-\mathrm{NaCl}$ and $0.05 \mathrm{M}$-EDTA at

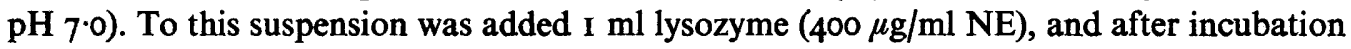
for $60 \mathrm{~min}$ at $37^{\circ} \mathrm{C}$ the cells were lysed by adding $16.5 \mathrm{ml}$ of solution BDE (I \% BRIJ-58, $0.04 \%$ deoxycholate, $0.3 \mathrm{M}$-EDTA, pH 8.0) and gently swirling for $5 \mathrm{~min}$ at $20^{\circ} \mathrm{C}$. A sample $(2 \mathrm{ml})$ of the supernatant obtained by centrifugation of the lysate at $50000 \mathrm{~g}$ for $15 \mathrm{~min}$ at $0{ }^{\circ} \mathrm{C}$ was mixed with $3 \mathrm{ml}$ of $64 \%(\mathrm{w} / \mathrm{w}) \mathrm{CsCl}$ containing $550 \mu \mathrm{g}$ ethidium bromide $/ \mathrm{ml}$ and centrifuged in an L2-50 centrifuge (Beckman Instruments, Glenrothes, Fife) at $144000 \mathrm{~g}$ $\left(r_{\mathrm{av}} 7 \cdot 3 \mathrm{~cm}\right)$ for $36 \mathrm{~h}$ at $15{ }^{\circ} \mathrm{C}$ using an SW 50L rotor. The tubes were examined in an ultraviolet light source (model LH 530; Gallenkamp, London).

This procedure was repeated using a culture inoculated $(0.3 \%)$ from a $20 \mathrm{~h}$ culture which had lost its urease activity following treatment with ethidium bromide at $3 \times 10^{-5} \mathrm{M}$. 


\section{RESULTS}

\section{Effect of inoculum size on culture urease activity of S. faecium}

Although urease activity in subcultures could always be retained by using a $2 \%(\mathrm{v} / \mathrm{v})$ inoculum, during a period after the isolation of $S$. faecium repeated subculturing in the urea-free media SY and SBY using a $0.3 \%$ inoculum resulted in cultures which had no urease activity when tested by subculturing into the same media containing urea, i.e. from SY to SU or from SBY to SBU media. From two to six subcultures in either SY or SBY media resulted in loss of activity, and activity was not restored by subsequent repeated, subculturing in urea-containing media. The loss of urease activity was demonstrated in four separate experiments, with triplicate cultures in each, over a period of six to nine months after isolation. However, when these experiments were later repeated, from twelve months to two years after the isolation of the streptococcus, the urease activity was not lost.

\section{Effect of incubation temperature on the synthesis of urease by $S$. faecium}

Since similar results were obtained with both media, only the results from SU medium are quoted in Table $\mathrm{I}$. At temperatures above $38^{\circ} \mathrm{C}$ bacterial growth was reduced, although there is some evidence for an adaptation to the higher temperatures in the third and fourth subcultures. With the higher temperatures urease activity also decreased, but the activity was regained on subculture at $38^{\circ} \mathrm{C}$. At temperatures below $38^{\circ} \mathrm{C}$ bacterial growth increased to a maximum between 36 and $29{ }^{\circ} \mathrm{C}$ and then decreased. At temperatures below $30^{\circ} \mathrm{C}$ urease activity decreased and was permanently lost during culture at 22 or $18{ }^{\circ} \mathrm{C}$.

\section{The effect of SDS on growth and urease activity of S. faecium}

SDS was included in SBU medium at concentrations from 0.0005 to $0.0050 \%(0.0005 \%$ increments). Up to $0.0010 \%$ SDS, there was no inhibition of growth and all the cultures were ureolytic. After one subculture in $0.0015 \%$ SDS there was a marked reduction in the density (6.8 extinction units compared with 39 ), but after the second subculture the density had recovered to 37 units. The viable counts (c.f.u./ml) in these cultures were $2 \times 10^{7}$ and $9.8 \times 10^{8}$, respectively, and $1.48 \times 10^{9}$ in the control. The four cultures grown in $0.0015 \%$ SDS were not ureolytic. However, when any of these cultures was transferred to SDS-free SBU medium, growth and urease activity were regained. At $0.0020 \%$ SDS the growth density in the first subculture, which was not ureolytic, was $4^{\circ} 0$ units and the viable count was $7.2 \times 10^{6} \mathrm{c} . \mathrm{f}$.u./ml. The density in the second subculture increased to 10.1 units $\left(7.4 \times 10^{7}\right.$ c.f.u. $\left./ \mathrm{ml}\right)$. In the fourth subculture with $0.0020 \%$ SDS the density had increased to 13.5 units $\left(\mathrm{I} \times 10^{8} \mathrm{c.f}\right.$.u. $\left./ \mathrm{ml}\right)$, but neither culture was ureolytic. The bacteria from the first subculture in the presence of $0.0020 \%$ SDS regained urease activity and growth similar to the control values when transferred to SDS-free medium, but bacteria from the second subculture in the presence of SDS did not regain activity even after 2I successive transfers in SDS-free medium, although growth was similar to the control. The density of the first subculture grown in the presence of $0.0025 \%$ SDS was 3.5 units, and even after three further subcultures at this SDS concentration there was no increase in culture density although there was an apparent marginal increase in viable count - from $6.6 \times 10^{6}$ c.f.u. $/ \mathrm{ml}$ in the first subculture to $7 \times 10^{6}$ in the fourth. One subculture in the presence of $0.0025 \%$ SDS was sufficient to produce permanent loss of urease activity, although the density in the nonureolytic cultures in SDS-free medium was similar to the control. With SDS at a concentration of $0.0030 \%$ and above there was no visible growth. 


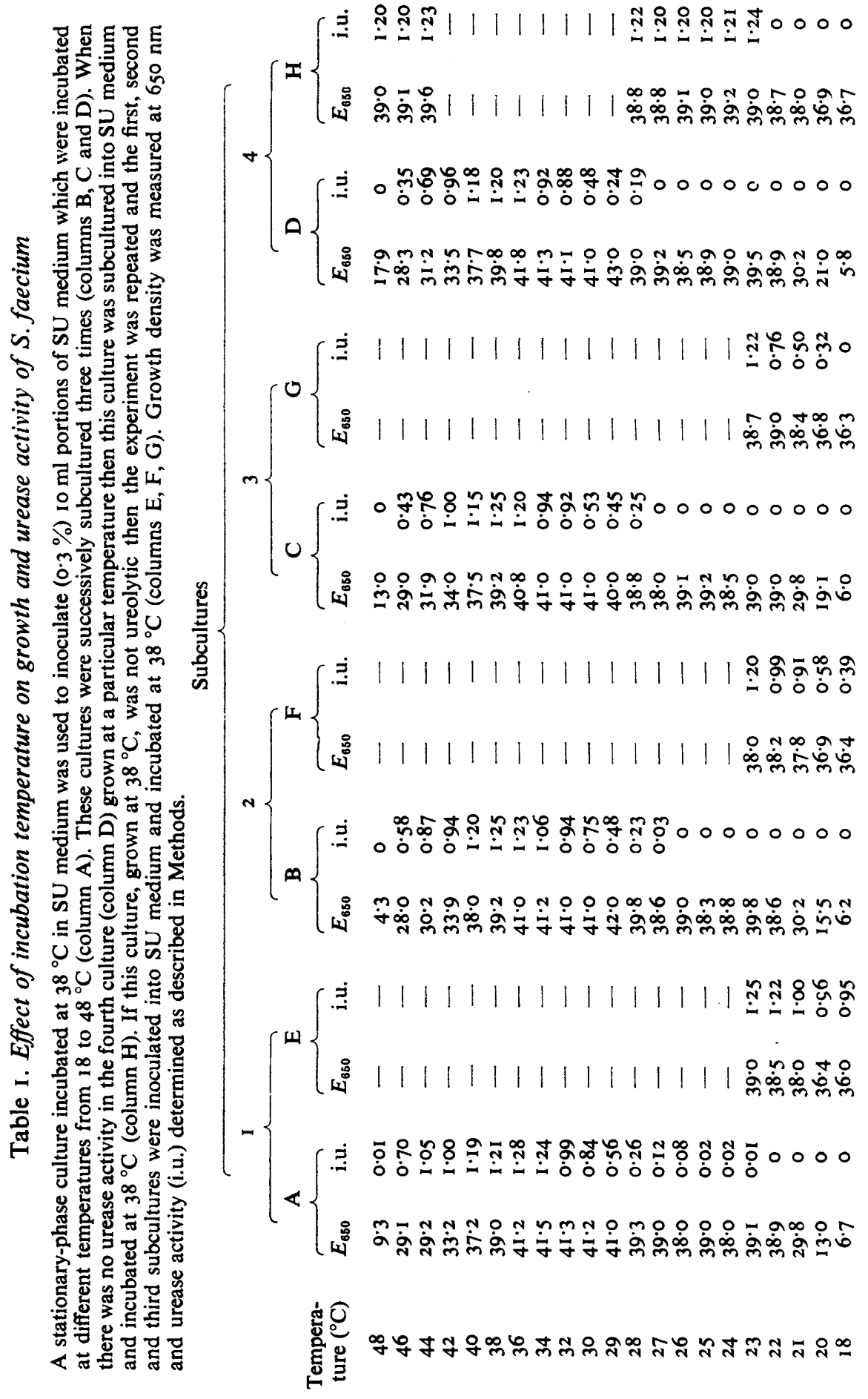




\section{The effect of $E B$ on the growth and urease activity of $S$. faecium}

In the first cultures, there was an inhibition of growth with increasing concentrations of $\mathrm{EB}$, with growth ranging from 29.0 units at $9 \times 10^{-6} \mathrm{M}$ (the density of the control was 38 units) to not measurable at $3.0 \times 10^{-5} \mathrm{M}$ and greater concentrations. At $2.5 \times 10^{-5} \mathrm{M}$-EB, the density was 2.4 units and the viable count $2.6 \times 10^{6}$ c.f.u./ml after one culture. After four subcultures the density had increased to $1 \mathrm{I} \cdot 8 \mathrm{units}$ and the viable count to $8 \times 10^{7}$ c.f.u./ $\mathrm{ml}$, but there was no measurable urease activity in any culture. However, while ureolytic activity was regained when the first two subcultures with EB were transferred to EB-free medium, when the third subculture was used as inoculum the urease activity was not regained. The action of $3 \times 10^{-5} \mathrm{M}-\mathrm{EB}$ was similar. Thus, in the first culture there was no measurable density, although the viable count was $2.6 \times 10^{5} \mathrm{c.f} . \mathrm{u} . / \mathrm{ml}$; after the fourth subculture the density was $9 \cdot 1$ and the count $2 \cdot 8 \times 10^{7}$ c.f.u. $/ \mathrm{ml}$. None of the four cultures grown in $3 \times 10^{-5} \mathrm{M}$-EB were ureolytic although after two subcultures in EB-free medium the bacteria from the first subculture in EB regained the urease activity. Urease activity was permanently lost after the second subculture in medium with EB. There was no measurable growth in the first culture in $3.5 \times 10^{-5} \mathrm{M}$-EB; the density after four subcultures increased to 8.2 units, and the count increased from $2 \times 10^{5}$ to $2.5 \times 10^{7} \mathrm{c.f} . \mathrm{u} . / \mathrm{ml}$. Urease was lost after two subcultures at $3.5 \times 10^{-5} \mathrm{M}-\mathrm{EB}$.

\section{The effect of EB on the growth and urease activity of $P$. mirabilis}

There was a reduction in culture density from a control value of 30.6 units to 23 and $15 . \mathrm{I}$ after one culture in $6 \times 10^{-5}$ and $1 \times 10^{-4} \mathrm{M}-\mathrm{EB}$, respectively. Two further subcultures in $1 \times 10^{-4} \mathrm{M}$-EB resulted in a slight increase in culture density from 15.1 to 20 units. The density in the first culture in $2 \times 10^{-4} \mathrm{M}$-EB was zero but in the second culture was 16.4 units. An EB concentration of $3 \times 10^{-4} \mathrm{M}$ was completely inhibitory; there was no measurable growth in successive subcultures and no colonies were formed when these cultures were plated on brain-heart infusion agar. All the cultures grown in the presence of $1 \times 10^{-4} \mathrm{M}$-EB were ureolytic. In $2 \times 10^{-4} \mathrm{M}$-EB the urease activity of the first culture was not measurable because of insufficient growth, but 100 colonies isolated from this culture were all ureolytic. In the succeeding subcultures grown in $2 \times 10^{-4} \mathrm{M}-\mathrm{EB}$, urease could be measured but it was only about half that of the control.

\section{Effect of EB on growth and urease activity of $P$. provostii}

The culture density in medium AE without EB was 80 units and the effect of increasing concentrations of EB was to inhibit growth, until at $4.5 \times 10^{-6} \mathrm{M}$ there was no measurable growth. At $4 \times 10^{-6} \mathrm{M}$ the culture density was $\mathrm{I} \cdot 7$ units and urease activity was very small, while at $3.5 \times 10^{-6} \mathrm{M}$ the density was 21.9 units and the culture was definitely ureolytic. Further subcultures in the presence of $\mathrm{EB}$ at $4.5 \times 10^{-6} \mathrm{M}$ did not result in any increase in growth, but with $4 \times 10^{-6} \mathrm{M}$ the culture density increased to $13.8,26.9$ and $8 \mathrm{I}$ units in successive subcultures, while in the presence of $3.5 \times 10^{-6} \mathrm{M}-\mathrm{EB}$ the density increased to 72 units after two subcultures. Urease activity could be measured in all subcultures in either $4 \times 10^{-6}$ or $3.5 \times 10^{-6} \mathrm{M}-\mathrm{EB}$, and all the 100 colonies isolated from the culture incubated once in the presence of $\mathrm{EB}$ at $4 \times 10^{-6} \mathrm{M}$ were positive.

\section{Effect of aeration on urease activity of $S$. faecium}

Bacteria grown for $24 \mathrm{~h}$ under aerobic conditions are not ureolytic and activity is not regained in subsequent anaerobic subcultures (Cook, 1976). The present experiments tested 
Table 2. Effect of aeration on growth density and urease activity of $S$. faecium

The growth density $\left(E_{650}\right)$ and urease activity (i.u.) of an aerobic culture of $S$. faecium grown in SBU medium ( $105 \mathrm{ml}$ ) at $38^{\circ} \mathrm{C}$ without sodium thioglycollate and aerated at $3000 \mathrm{ml} / \mathrm{min}$. Anaerobic SBU medium was inoculated at $0.5 \mathrm{~h}$ intervals with inocula from the aerobic culture and grown for either 24 or $48 \mathrm{~h}$ at $38^{\circ} \mathrm{C}$. The anaerobic cultures grown for $24 \mathrm{~h}$ were subcultured into SBU medium and incubated a further $24 \mathrm{~h}$. The growth density was measured at $650 \mathrm{~nm}$ and urease activity was determined for each subculture. Urease activity of the aerobic culture was determined as described in Methods; in the subculture, $1 \mathrm{ml}$ of culture was resuspended after centrifugation, in $\mathrm{I} \mathrm{ml}$ of the assay buffer, and a $0.2 \mathrm{ml}$ sample assayed overnight. The result was scored as positive $(+)$ or negative $(-)$.

\begin{tabular}{|c|c|c|c|c|c|c|c|c|}
\hline \multirow{3}{*}{$\begin{array}{l}\text { Time } \\
\text { (h) }\end{array}$} & & & \multicolumn{6}{|c|}{ Anaerobic subcultures } \\
\hline & \multicolumn{2}{|c|}{ Aerobic culture } & \multicolumn{2}{|c|}{$\begin{array}{l}\text { First } \\
24 \mathrm{~h}\end{array}$} & \multicolumn{2}{|c|}{$48 \mathrm{~h}$} & \multicolumn{2}{|c|}{$\begin{array}{c}\text { Second } \\
24 \mathrm{~h}\end{array}$} \\
\hline & $E_{650}$ & i.u. & $E_{650}$ & Urease & $E_{650}$ & Urease & $E_{650}$ & Urease \\
\hline 0 & 0 & 0.0012 & $42 \cdot 5$ & + & $29 \cdot I$ & & $50 \cdot 0$ & \\
\hline 0.5 & 0.5 & 0.0012 & $38 \cdot 8$ & + & $30 \cdot 2$ & & $47 \cdot 7$ & \\
\hline $1 \cdot 0$ & $1 \cdot 3$ & 0.0011 & $39 \cdot 0$ & + & $3 I \cdot I$ & & $47 \cdot 8$ & \\
\hline $1 \cdot 5$ & $2 \cdot 3$ & 0.0012 & $40 \cdot 2$ & + & $30 \cdot 9$ & & $46 \cdot 0$ & \\
\hline $2 \cdot 0$ & $2 \cdot 8$ & 0.0011 & $40 \cdot 0$ & + & $3 I \cdot 2$ & & $47 \cdot 0$ & \\
\hline $2 \cdot 5$ & 3.6 & 0.0010 & $38 \cdot 0$ & + & $28 \cdot 8$ & & $46 \cdot 8$ & \\
\hline $3 \cdot 0$ & 4.9 & 0.0011 & $36 \cdot 8$ & + & $27 \cdot 4$ & & $46 \cdot 8$ & \\
\hline $3 \cdot 5$ & $8 \cdot 3$ & 0.0011 & $3 I \cdot 3$ & + & $23 \cdot 0$ & & $46 \cdot 8$ & \\
\hline $4 \cdot 0$ & $15 \cdot 3$ & 0.0010 & $26 \cdot 8$ & + & $16 \cdot 7$ & & $44 \cdot 2$ & + \\
\hline $4 \cdot 5$ & $22 \cdot 8$ & 0.0009 & $20 \cdot 1$ & - & $13 \cdot 5$ & + & $43 \cdot 8$ & + \\
\hline $5 \cdot 0$ & $28 \cdot 8$ & 0.0006 & I $8 \cdot 6$ & - & $8 \cdot 8$ & - & $41 \cdot 5$ & - \\
\hline $5 \cdot 5$ & $32 \cdot 8$ & 0.0006 & $16 \cdot 0$ & - & $6 \cdot 4$ & - & $44 \cdot 2$ & - \\
\hline $6 \cdot 0$ & $43 \cdot 8$ & 0.0005 & 14.9 & - & $5 \cdot 1$ & - & $42 \cdot 9$ & - \\
\hline $6 \cdot 5$ & $44 \cdot 8$ & 0.0004 & $14 \cdot 0$ & - & $5 \cdot 0$ & - & $42 \cdot I$ & - \\
\hline $7 \cdot 0$ & $47 \cdot 8$ & 0.0004 & 13.0 & - & $4 \cdot 8$ & - & 42.5 & - \\
\hline $7 \cdot 5$ & $48 \cdot 8$ & 0.0002 & 12.5 & - & $5 \cdot 0$ & - & $42 \cdot 3$ & - \\
\hline 8.0 & $48 \cdot 5$ & 0.0002 & $13 \cdot 2$ & - & $5 \cdot 2$ & - & $42 \cdot 0$ & - \\
\hline $8 \cdot 5$ & $48 \cdot 7$ & 0.0001 & 13.0 & - & $5 \cdot 0$ & - & $42 \cdot 4$ & - \\
\hline $9 \cdot 0$ & $48 \cdot 3$ & 0.0000 & $12 \cdot 8$ & - & $4 \cdot 8$ & - & $42 \cdot I$ & - \\
\hline
\end{tabular}

the effects of aeration in more detail. After $5 \mathrm{~h}$ aeration urease activity was permanently lost, as it could not be restored by continued anaerobic subculture (Table 2).

\section{Isolation of plasmid DNA (CCC) by dye-buoyant density centrifugation}

Examination of the centrifuge tubes after density centrifugation showed the presence of only one band, equivalent to that present in the centrifugate of DNA obtained from ureasenegative bacteria treated with EB.

\section{DISCUSSION}

Conjugation ability, production of colicins, and some (but not all) resistance to antibiotics and inorganic ions appear to be coded only on extrachromosomal genetic determinants (plasmids), but there is now increasing evidence that there can be other plasmid-coded bacterial characters.

Richmond (1972) listed five criteria for the identification of the extrachromosomal location of genes, and the first of these criteria refers to the high frequency of loss. It was observed during the isolation of $S$. faecium that urease activity was not present in all the bacteria. Thus the streptococcus was usually isolated without urease activity from dilutions of either the rumen or enrichment cultures, and even most of the colonies isolated from a 
diluted, ureolytic, pure culture of $S$. faecium were not ureolytic. It was thus tentatively suggested (Cook, 1976) that the genetic coding for urease might be sited on a plasmid. Urease activity was retained in the mixed enrichment subcultures made before the isolation of the streptococcus in pure culture, but a large inoculum $(\mathrm{I} \cdot 5 \%, \mathrm{v} / \mathrm{v})$ was used for these. In the mixed continuous culture system of the normal rumen the streptococcus appears to produce most of the relatively constant urease activity, and a gnotobiotic lamb inoculated with the streptococcus and other bacteria had a stable rumen-urease level (Cook, 1976).

The first criterion of Richmond (1972) states that the loss frequency should be quantified, to differentiate the high frequency of loss associated with plasmids from that of the spontaneous mutation rates of most genes. With the urease activity of $S$. faecium it has not been possible to evaluate such a figure, since virtually all the colonies isolated from a diluted pure culture were non-ureolytic and so only an 'all-or-nothing' effect could be obtained.

Another criterion listed by Richmond (1972) is the effect of growth at elevated temperatures on the spontaneous rate of loss of a plasmid-borne property (Fairbrother, Parker \& Eaton, I954). With $S$. faecium, while there was no measurable urease activity in a culture incubated at $48^{\circ} \mathrm{C}$ and thus the rate of spontaneous loss was increased at this temperature, activity returned after subculture at $38^{\circ} \mathrm{C}$, which is both the usual culture temperature and the temperature of the rumen. Lowering the incubation temperature, however, presumably caused a greater rate of loss, resulting in a permanent deletion of urease activity at $22{ }^{\circ} \mathrm{C}$ and below.

The effect of chemical agents on the spontaneous rate of loss of a genetic marker is a further criterion of Richmond (1972). The chemical agents used in this study were (i) SDS which may act by disrupting the plasmid-membrane attachment site (Sonstein \& Baldwin, $1972 b$ ), and (ii) the trypanocidal drug EB, which, like the acridine dyes, intercalates between base pairs of DNA, thus indirectly hindering the action of DNA and RNA polymerases (Waring, 1966). With $S$. faecium, one subculture in the presence of $0.0025 \%$ SDS was sufficient to 'cure' the bacterium of ureolytic activity, and with SDS at $0.0020 \%$ two subcultures were needed to obtain a non-ureolytic culture.

The effect of EB on the elimination of urease activity from $S$. faecium was compared with the effect of this 'curing' agent on the urease activity of Proteus mirabilis and Peptostreptococcus provostii. Streptococcus faecium was 'cured' of urease activity when subcultured three times in the presence of EB at $2.5 \times 10^{-5} \mathrm{M}$, which was less than the minimal inhibitory concentration of EB at $3 \times 10^{-5} \mathrm{M}$. On the other hand P. mirabilis and Pep. provostii still retained urease activity even at EB concentrations at which there was no measurable growth. The results of Bouanchaud, Scavizzi \& Chabbert (1969) with five strains of Staphylococcus aureus support the present results with $S$. faecium in that they found that $5 \times 10^{-6}$ to $10 \times 10^{-6} \mathrm{M}$-EB eliminated pencillin resistance in the staphylococcus. Similarly Sonstein \& Baldwin (1972 $a$ ) found the highest rate of elimination of plasmid-coded penicillin resistance in Staph. aureus was with $3 \times 10^{-5} \mathrm{M}-\mathrm{EB}$, and Courvalin et al. (1972) 'cured' Streptococcus faecalis of tetracycline resistance with $\mathrm{EB}$ at $2.5 \times 10^{-5} \mathrm{M}$.

Thus the actions of SDS and EB, and the growth conditions of low temperature and aeration, resulted in the loss of urease activity from $S$. faecium, and it is proposed that these results are evidence for a plasmid-coded urease. The inability to isolate a plasmid from the $S$. faecium is not, of course, necessarily proof of its non-existence. If, in fact, only about $I \%$ of the cells in a culture are urease-positive then sufficient CCC DNA for detection by ultra-violet examination might not be present. This possibility is being investigated.

Another possible explanation is that the loss of urease activity may be the result of one of two kinds of chromosomal mutation. In the first, a mutator gene may be present which 
greatly enhances the frequency of point mutations of certain sites in permanently chromosomal genes (Richmond, 1972). In the second, the insertion of a few nucleotide pairs into the continuity of a chromosomal gene (e.g. urease) would result in a spontaneous mutation (Jordan, Saedler \& Starlinger, 1968). Saedler \& Heib (1973) proposed that a small plasmid may fulfil this role of carrying an insertion sequence, but were not able to detect such.

I thank Mrs M. Cowie and Miss I. Black for technical assistance and Dr P. N. Hobson for helpful discussions.

\section{REFERENCES}

Bazaral, M. \& Helinski, D. R. (1968). Circular DNA forms of colicinogenic factors Er, E2 and E3 from Escherichia coli. Journal of Molecular Biology 36, 185-194.

Bouanchaud, D. H., Scavizzi, M. R. \& ChabberT, Y. A. (1969). Elimination by ethidium bromide of antibiotic resistance in Enterobacteria and Staphylococci. Journal of General Microbiology 54, 41 7-425.

Christiansen, C., Christiansen, G., Bak, A. L. \& Stenderup, A. (1973). Extrachromosomal deoxyribonucleic acid in different Enterobacteria. Journal of Bacteriology II4, 367-377.

CLowes, R. C. (1972). Molecular structure of bacterial plasmids. Bacteriological Reviews 36, 361-405.

CoOK, A. R. (1976). Urease activity in the rumen of sheep and the isolation of ureolytic bacteria. Journal of General Microbiology 92, 32-48.

Courvalin, P. M., Carlier, C. \& Chabbert, Y. A. (1972). Plasmid-linked tetracycline and erythromycin resistance in group D Streptococcus. Annales de l'Institut Pasteur 123, 755-759.

EuiAs, A. (1971). The rumen bacteria of animals fed on a high-molasses-urea diet. Ph.D. thesis, University of Aberdeen.

Fairbrother, R. W., Parker, L. \& Eaton, B. R. (1954). The stability of penicillinase-producing strains of Staphyloccocus aureus. Journal of General Microbiology 10, 309-316.

Jordan, E., Saedler, H. \& Starlinger, P. (1968). $0^{\circ}$ and strong-polar mutations in the gal operon are insertions. Molecular and General Genetics 102, 353-363.

Novick, R. P. (1969). Extrachromosomal inheritance in bacteria. Bacteriological Reviews 33, $210-235$.

Richmond, M. H. (1972). Plasmids and extrachromosomal genetics in Staphylococcus aureus. In Staphylococci, pp. 1 59-1 86. Edited by J. O. Cohen. New York: Interscience.

SAEDLER, H. \& HEIB, B. (I973). Multiple copies of the insertion-DNA sequences ISI and IS2 in the chromosome of E. coli K-12. Molecular and General Genetics 122, 267-277.

SonsteIn, S. A. \& Baldwin, J. N. (1972a). Loss of the penicillinase plasmid after treatment of Staphylococcus aureus with sodium dodecyl sulphate. Journal of Bacteriology 109, 262-265.

Sonstein, S. A. \& Baldwin, J. N. $(1972 b)$. Nature of the elimination of the penicillinase plasmid from Staphylococcus aureus by surface-active agents. Journal of Bacteriology III, I 52-I 55.

WARING, M. J. (1966). Cross-linked and intercalation in nucleic acids. Symposia of the Society for General Microbiology 16, 235-265. 